\title{
Self- resistance in Dina Mehta's Getting Away with Murder
}

\author{
L. Jeevitha, Dr. G. Subramanian \\ Assistant Professor, Nehru Arts and Science College, Coimbatore, TN, India \\ Assistant Professor, Government Arts College, Coimbatore, TN, India
}

Dina Mehta is an Indian writer belonging to the Parsi community. Among the Indian writers belonging to the community of Parsi's, Dina Mehta is prominent. Generally, the Parsi novelists who write in English are differentiated into two categories; expatriate writers and stay-at-home writers and Dina Mehta falls into the category of stay-athome writers. Other Parsi novelists like Firdaus Kanga, Rohinton Mistry, Farrukh Dhondy and Bapsi Sidhwa are included in the list of expatriate novelists. The work of these novelists reflects the life of their community and the history of India. Their works also portray their ethnic identity and relationships like motherhood, intricate baffling relationship of men and women, incest and adultery.

Dina Mehta's Getting Away With Murder deals with various issues like child abuses, rape, female feticide, and blind superstitious belief that are the hindrance in the development of human development, but this play voices against foeticide, infanticide, rape, inequality, and gender discrimination. This play portrays the independent thinking modern women who work to rise up herself and world around with her conscience thoughts, and harmony.

Getting away with murder is one of the three plays in the collection entitled "Body blows- women violence and survival" published by Seagull books, Calcutta in 2000. The play was first performed by Indus International, a sociocultural group for women at British Council Theatre in Mumbai in 1990. The play seeks to portray the lives of three friends Mallika, Sonali and Raziya who are connected perhaps by the strain of suffering that they undergo in the hands of male hypocritic and dominating human. The private world outside so corrupted that women have to face childhood sexual abuse, differential treatment on the male and the female child, infidelity partners with whom they have an utterly insecure relationship, sexual harassment at workplace and elsewhere, and a disheveled life despite having been educated.

In this play, the author addresses various issues like voicing against foeticide, infanticide, rape, and gender discrimination. The play portrays the lives of three women who are dealing with different types of assault like child abuses, infanticide and gender discrimination. Sonali, is a victim of childhood sexual abuse this had led her to psychosis and the later death of her villain uncle help her to expel herself out of that incident which keeps haunting her nightmares. Her psyche problem provoked her to commit the female foeticide during her previous pregnancy to avoid "violence and servitude" (63) for her unborn girl-child. Due to her childhood incident she even in the third month of her pregnancy did not inform her husband about this because she wants her friend Mallika (Malu) to ask Dr. Raziya to perform amniocentesis on her to find out the sex of the unborn child. Sonali confesses to Mallika that if a woman cannot give birth to a son it mean she has done some misdeeds in her past life. The whole argument goes in this manner:

SONALI: Call it what you like. It is still my body and my choice. A symbol of my emancipation.

MALU: What is? Female feticide? My God, this is like something out of a black comedy. Mothers award the death sentence to their unborn daughters in the name of liberation. They thereby prove their woman-power! Their omnipotence! They play God!

SONALI: Shut up, shut up! (Thumping the table) To be born a girl is to be subject to violence and servitude! I know, I know! (Getting Away 63)

Sonali tries to justify her female foeticide and her attempt of sex detection in her next pregnancy is her emancipation and her rights though she knows that amniocentesis is banned. Mallika gets annoyed and says:

"I thought only ignorant women had this prejudice or depraved women with drudgery as their lot, who are sucked into further poverty and debts when they spawn daughters because girls need dowries... But to someone like you, how can it matter if the first child is a boy or girl?" (62). 
Here the desperate violence of abortion which she committed on her own body by herself to get away with the female foetus is interpreted by her as a mode of emancipation and this shows how the idea of woman's freedom of choice is structured by patriarchal society. At the end of the play, Sonali, breaks free from her nightmarish and she is empowered, where she is able to speak and overcome her fear with help of her husband Arun who says that he don't mind even if have a girl child and he wish for a girl child only.

Next character is Mallika a successful and bold women, who rejects the advances of her male co-worker. She works with Mr. Pingle, who is a male chauvinist and restricts her only to do secretarial work.Her co-partner tells her that women should either do secretarial work or maximum to PR work. He even fixes up her lunch with clients without her knowledge just to put her in problem and create inconvenience.However he disturbs Mallika because she was always there forward in all the business dealings and running the entire office. She even rescued Thelma, her secretary, who was sexually harassed and blackmailed her with the phone calls that she made some time back by her co- partner. Thelma says:

"he - he makes vulgar talk... and wicked gestures... asking me to accompany him to hotels outside the city" (Getting Away 70).

About Mallika's ambiguous relationship with Sonali's brother Gopal an irresponsible lover, but he was involved in the upliftment of women protesting against the practice of burning women in rural areas were people believed that women are witches. He even took care of Minzari's daughter after her death. There are some events that indicate the illicit relationship between Gopal and Minzari. In a conversation between Mallika and Gopal, he says:

"What do you want me to say? That I screw every woman I meet because I'm sick and tired of an old hag like you..." (Getting Away 84)

On the other hand, Raziya, a successful doctor and an individual women but a victim toantiquated society. She gives self-infliction by accepting for the second marriage of her husband, just because she cannot bear any child, by which she fails to become a traditional wife as a childbearer. Raziya's troubled relationship with her husband can also be seen in the light of atrocity, when she knew her husband Habib's affair with his niece Fatima's friend Zamena, whom even he plans to marry. But she didn't react because she cannot have a child of her own. When Malu questions Raziya, she says:

"I find an ancient tyranny at work within me that makes me believe that a man's desire for children must be satisfied. Just as Sonali believes that a woman's inferior status is partially redeemed when she becomes a mother of sons. And just as you, my dear Malu, believe that a man has the right to the body of a woman younger that he..." (Getting Away 77).

Even though Raziya decides not to react, she becomes empowered when she declares that:

“... don't fool yourself that you and I are so different Malu! Or that by identifying man as villain we have won our fight for equality! The enemy is within, don't you see? It's in our minds, Mallika that we are underlings!'(78)

Indian English playwrights used the theatre as a tool to raise voice against the gender discrimination and also record opposition against issues like child abuses,eve-teasing, subjugation, suppression, rape, sexual harassment, female feticide, blind superstitious beliefs, gender discrimination and inequality. They adopted theatre as a practical mean to fight against such misdemeanor which cannot be discussed in any mode to the public.

Dina Mehta also used the theatre for portraying her resistance against violence like child abuses, rape, female feticide, blind superstitious beliefs, gender discrimination and inequality, which is often the order of the day in the andro-centric world. In Getting away with murder Dina Mehta's female charactersSonali, Mallika and Dr. Raziya voice out the concept of male gaze were women are represented as a victim to this male dominated society and as a sex object. These chosen characters protect against the patriarchal treatment which shows that they are empowered women. They decided not to be lifeless in the hands of owns and didn't want their life to be controlled by others. Dina mehta's plays are a challenge to false patriarchal theory that women is meant to be a subject of violence and suppression, which they are really not. G.D. Anderson once said, "Feminism isn't about making women strong. It's about changing the way the world perceives that strength." Women empowerment means helping them to take their own decisions by breaking all personal limitations of the society and family by which the women get emancipated from the shackles of patriarchal society and now it's the 
turn of the common people to contribute positively for the cause.

\section{REFERENCES}

Aston, Elaine. "Finding a Tradition: Feminism and Theatre History", An Introduction to Feminism and Theatre. London and New York: Routledge, 1995.

Dr.Sharma,Shuchi.'Interrogating Phallocentrism: A Study of Select plays by Indian English Women Playwrights." Research Journal of English Language and Literature. 3.2.2015:1-5 4

Mehta, Dina. Getting Away with Murder. Body Blows:Women,Violence and Survival. Calcutta: Seagull Books,2000. 